\title{
Urban forestry research needs identified by Canadian municipalities
}

\author{
by Jacques Larouche ${ }^{1 *}$, Danny Rioux², Adrina C. Bardekjian ${ }^{3}$ Nancy Gélinas ${ }^{1}$
}

\begin{abstract}
At a time when the future of our planet remains fraught with uncertainty, interest in the state and role of forests, especially in urban settings, is growing rapidly. Our project, based on a Canada-wide survey, identifies the research needs of 192 municipalities of 5000 inhabitants or more, and verifies whether the size of the municipality, the region or the canopy have an impact on these needs. The numerous needs identified by municipalities show that there is a strong demand for research in this area. In particular, municipalities want to know: a) which tree species are better adapted to urban settings; b) the effects of trees on rainwater runoff and on human health; and c) that more studies be conducted on topics such as trees and infrastructure, on hazardous trees, on invasive plant species, and on various tree pests. Our analysis reveals that small municipalities are less interested in certain needs than larger municipalities, and that municipalities in the Maritimes region show more interest in certain topics than those in other Canadian regions. Results also reveal that urban forest canopy size has no influence on the identified needs. This study allows researchers to better define their projects, and it highlights the importance of improving knowledge exchange with and among key stakeholders in cities actively pursuing and interested in urban forestry activities.
\end{abstract}

Key words: management, parks, arboriculture, green spaces, urban forestry

\section{RÉSUMÉ}

À un moment où l'avenir de notre planète semble incertain, l'état et le rôle des forêts, particulièrement en milieu urbain, attirent de plus en plus l'attention. Notre projet, basé sur une enquête auprès de 192 villes canadiennes de 5000 habitants et plus, identifie leurs besoins de recherche et vérifie si ceux-ci sont influencés par la taille, les régions ou la canopée des villes canadiennes. Les nombreux besoins identifiés montrent qu'il y a une forte demande dans ce domaine. En particulier, il y a un besoin concernant : a) les espèces les mieux adaptées au milieu urbain; b) l'impact des arbres sur les eaux de ruissellement et la santé humaine; et c) les arbres et les infrastructures, les arbres dangereux, les plantes envahissantes et divers ravageurs des arbres. Nos analyses montrent que les petites municipalités sont moins intéressées par ces recherches que les grandes villes et que les municipalités de la région des Maritimes manifestent plus d'intérêt pour certains sujets que celles des autres régions canadiennes. La canopée n’a pas influencé les réponses des répondants. Cette étude permet aux chercheurs de mieux cibler les priorités de recherche et montre qu'il faut améliorer le transfert des connaissances vers les gestionnaires municipaux activement impliqués dans ce domaine.

Mots-clés : aménagement, parcs, arboriculture, espaces verts, foresterie urbaine

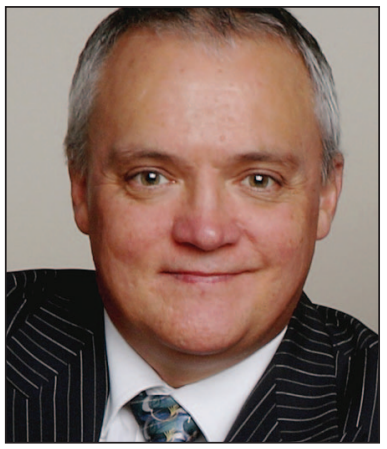

Jacques Larouche

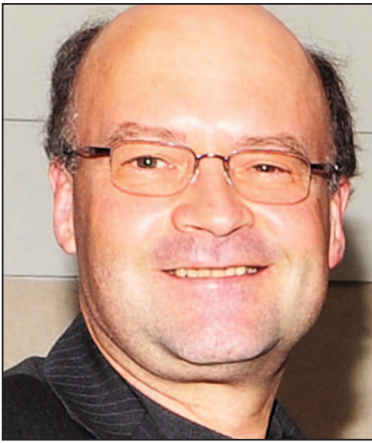

Danny Rioux

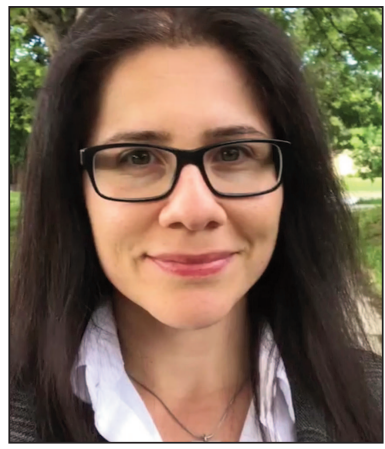

Adrina C. Bardekjian

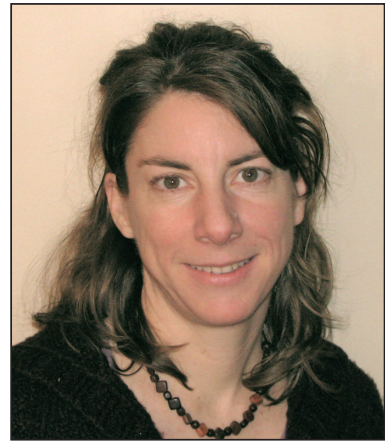

Nancy Gélinas

\footnotetext{
${ }^{1}$ Laval University, Abitibi-Price building, 2405 de la Terrasse, office 2145-A, Québec, Québec G1V 0A6, ${ }^{\star}$ Correspondence: jacques.larouche@canada.ca

${ }^{2}$ Natural Resources Canada, Forestry, Laurentian Forestry Center; 1055 du P.E.P.S., Succursale Sainte-Foy, Québec, QC, G1V 4C7, Canada

${ }^{3}$ Tree Canada, 43 Eccles Street, Suite B, Ottawa ON K1R 6S3 Canada
} 


\section{Introduction}

Trees provide a number of ecological, social and economic benefits wherever they are found, particularly in urban areas. In cities, they improve air quality among other things. For example, they reduce the amount of $\mathrm{NO}_{2}$, a gas that is harmful to human health (Rao et al. 2014). They also cool the air and help reduce noise, especially with green wall systems (Labrecque and Teodorescu 2005). They increase biodiversity by providing habitat for wildlife, thereby promoting the presence of insects, birds and mammals in urban areas (Gillig et al. 2008). Tree planting helps to maintain the quality of soils, which are home to millions of living organisms per $\mathrm{cm}^{3}$ (Gillig et al. 2008). Moreover, in the context of climate change, trees greatly help in capturing $\mathrm{CO}_{2}$. For example, Gillig et al. (2008) reported that one hectare of 100 -year-old beech forest annually sequesters an average of $4800 \mathrm{~kg}$ of $\mathrm{CO}_{2}$.

Trees also have a positive effect on human health: "Visiting green areas in cities can counteract stress, renew vital energy, and speed healing processes" (FAO 2000), and as one of the consequences it also helps counter depression (Berman et al. 2012). A study conducted in the United States associates the loss of trees in urban areas due to an insect pest, the emerald ash borer, with the increased mortality rate related to cardiac and respiratory diseases (Donovan et al. 2013).

Finally, urban trees contribute to various economic aspects such as increasing home values (Wolf 1998; Howley 2007). They also help save energy by intercepting the sun's rays in the summer and protecting against winds in the winter (Alexander and DePratto 2014). A city with wooded areas is more appealing and offers a quality environment, which may attract tourists and companies with high economic and technological value (Gillig et al. 2008). A study estimated the value of trees in Toronto's urban forest at $\$ 7$ billion, an average value of $\$ 700$ per tree (Alexander and McDonald 2014).

Urban trees that are managed by municipalities comprise three types of trees: street trees, park trees and urban woodland trees (Sangster et al. 2011). Municipalities with good plans also encourage the stewardship of trees on private properties; in Toronto for instance, privately owned trees represent approximately $60 \%$ of the total 10.2 million trees reported (City of Toronto 2013). Although urban woodland and park trees are generally subjected to less stress than street trees in terms of soil conditions and water supply, they are also under stress factors such as those caused by air pollutants and mechanical injuries resulting from constant foot traffic in parks. Street trees are subjected to significant stress at all levels: soil, water availability, pollutants and injuries.

Across Canada, urban trees cover only a small area. However, they have a much more positive influence on the welfare of city dwellers than trees growing in forests. For example, a survey conducted in southern Ontario found that $84 \%$ of respondents considered the presence of trees in their immediate environment to be "very" important (Environics Research Group 2001, cited in Kenney 2003). It is therefore no surprise that groups of citizens are mobilizing to protect green spaces in urban areas (e.g., see Bissonnette et al. 2018).

Numerous investigations have been carried out in urban forestry, particularly in recent years (Larouche et al. 2019), to learn more about different aspects of urban forestry in various countries, and some of them have dealt specifically with their research needs (Konijnendijk et al. 2000, 2007; Wolf and Kruger 2010). In Canada, one of the tasks mentioned in the urban forest strategy for 2013-2018 (Tree Canada 2012) was to identify the needs and priorities in research for municipalities, the essence of the present study.

Tree Canada conducted a survey identifying the trend in Canada's urban forest (Bardekjian et al. 2016) with some questions on research where the three main needs identified were: determining new management methods, improving resilience to pests and diseases and better identifying urban tree species for climate adaptation. The study, however, had only 26 respondents across Canada, and thus is not a comprehensive and accurate representation of all municipal needs. Hence, the objective of this study was to identify more extensively the current urban forestry research needs of Canadian municipalities of 5,000 inhabitants or more. We also examined whether these needs were influenced by the size of the municipalities' populations, the region in which they are located, and/or the size of their tree canopy.

\section{Methodology}

We conducted a survey in Canadian municipalities with 5000 inhabitants or more. This number of inhabitants was chosen because we wanted to have good representation of various Canadian municipalities while eliminating the numerous smaller municipalities that likely do not have an urban forest strategic management plan (in Canada, there are more than 5500 municipalities and near $85 \%$ of them have less than 5000 inhabitants).

First, an interview guide was developed and subsequently validated over the telephone by nine representatives/specialists of the Canadian urban forest sector. These interviews made it possible to develop a questionnaire and to identify a set of research needs common to respondents.

Once validated, the questionnaire was emailed from April to August of 2015 to the 719 municipalities with more than 5000 residents. An email had been sent in advance to inform them of the upcoming survey and reminder emails were sent based on the response rate. The questionnaire was made available in both English and French through a website. To do so, we bought the domain names "Forub-urbfor.ca" and "Forub-urbfor.com" and rented a server for one year to compile the responses. LimeSurvey 1.91 (https://www.limesurvey.org/) was used to create the questionnaire and compile the responses.

\section{Questionnaire}

The survey included 28 questions divided into five sections: A) General; B) Problems and issues; C) Information Sources; D) Research activities; and E) Role of various organizations involved in urban forestry. This article deals only with the responses in Section D based on ongoing researches in municipalities and the identification of their needs in this field.

To do this, a list of 32 needs was drawn up based on the telephone interviews conducted prior to developing the questionnaire. These needs were divided into five topics (Table 1). Respondents had to identify their interest in each of the proposed research activities. 
Table 1. Grouping of research needs by topic

\begin{tabular}{|c|c|}
\hline Topics & Research needs \\
\hline A- Knowledge of forest heritage & $\begin{array}{l}\text { 1- Tree inventory } \\
\text { 2- Use of geomatics to locate urban trees } \\
\text { 3- Use of satellites for tree inventory } \\
\text { 4- Tree species diversity }\end{array}$ \\
\hline $\mathrm{B}$ - Insects and diseases & $\begin{array}{l}\text { 5- Identification of indigenous insects } \\
\text { 6- Identification of indigenous diseases } \\
\text { 7- Identification of alien insects } \\
\text { 8- Identification of exotic diseases } \\
\text { 9- Control methods for protecting trees from insects and diseases } \\
\text { 10- Insect control } \\
\text { 11- Disease control } \\
\text { 12- Biting insect control }\end{array}$ \\
\hline C- Benefits of trees and urban wooded areas & $\begin{array}{l}\text { 13- Impact of trees on urban pollution } \\
\text { 14- Impact of trees on rainwater runoff } \\
\text { 15- Impact of trees on human health } \\
\text { 16- Impact of trees on heat islands } \\
\text { 17- Impact of trees on shoreline stabilization }\end{array}$ \\
\hline D- Tree planting & $\begin{array}{l}\text { 18- Urban area soil mixtures } \\
\text { 19- Planting trenches } \\
\text { 20- Impacts of planting on infrastructure } \\
\text { 21- Tree species adapted to the urban environment }\end{array}$ \\
\hline E- Other & $\begin{array}{l}\text { 22- Weed control } \\
\text { 23- Tree felling and wood use } \\
\text { 24- Urban wildlife management } \\
\text { 25- Invasive plant species management } \\
\text { 26- Effects of snow clearance on trees } \\
\text { 27- Effects of de-icing salt on trees } \\
\text { 28- Effects of grass cutting on trees } \\
\text { 29- Trees and infrastructure } \\
\text { 30- Work on the genetic selection of trees } \\
\text { 31- Identification of hazardous trees } \\
\text { 32- Infrastructure safety }\end{array}$ \\
\hline
\end{tabular}

\section{Sampling plan}

To conduct the survey, the questionnaire was sent with a cover letter directly to the 719 municipalities using the email addresses listed on their respective websites. In many municipalities, especially smaller ones, there is no Urban Forestry Officer position, so the Public Works section was instead contacted in the hope that park maintenance was part of their responsibilities. When this was not possible, we sent the emails to the "Contact Us" tab of their websites and asked to transfer our request to the managers responsible of the park maintenance in the municipality. They were first sent out in April 2015 and again in July-August of the same year.

\section{Validity and reliability}

We verified the precision of the measurement scales using Cronbach's alpha coefficient, which ensures their homogeneity. The greater the homogeneity, the more the scale is precise in terms of the internal consistency of items, and the more we can trust the "true score" of the individual, thus reducing the measurement error that causes the total score to vary from one measurement to another over time (Statistical Package for Social Sciences [SPSS] site, Université de Sherbrooke 2013). All the scales used in the questionnaire had a Cronbach's alpha coefficient above 0.900 . These values are excellent since it is recommended that they at least exceed the threshold of 0.70 (SPSS de Université de Sherbrooke 2013). The data were analyzed using version 23 of the SPSS statistical analysis software.

\section{Choice of tests for data analysis}

To verify the homogeneity of the variances we used the Shapiro-Wilk normality test with SPSS. The Shapiro-Wilk test revealed that none of the variables using measurement scales was normally distributed. Non-parametric tests were conducted to verify whether any of our factors influenced the choice of research needs.

Since these variables were measured on an ordinal scale divided into categories, and because we wanted to compare independent sample averages, the non-parametric KruskalWallis test was performed (Ramousse et al. 1996). When sig- 


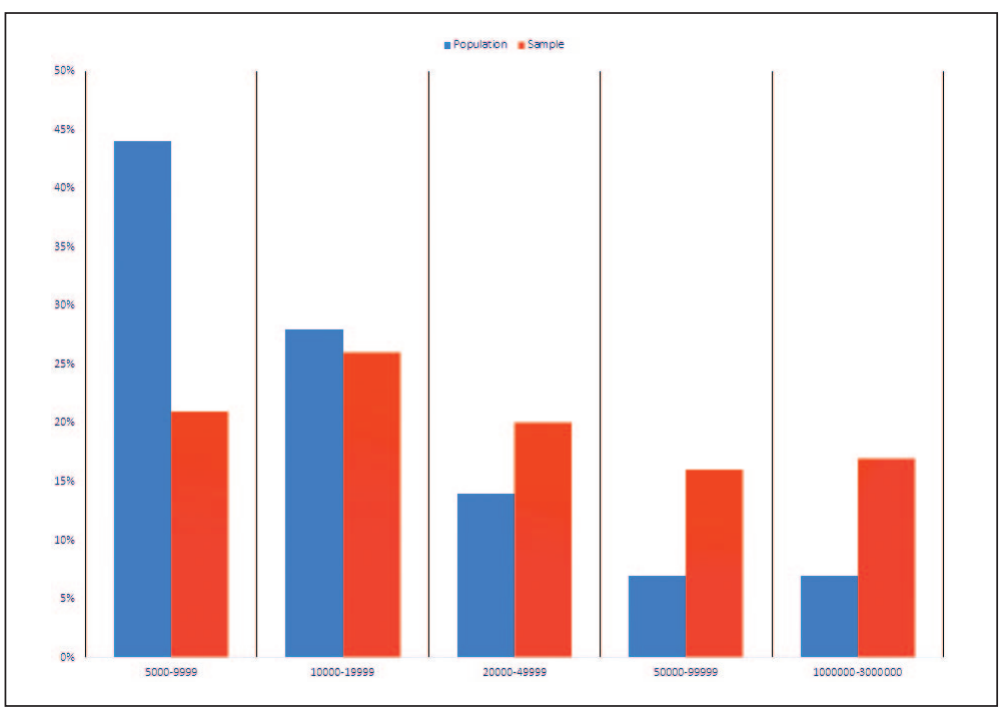

Fig. 1. Size of the municipalities: comparison of the responses received (Sampling) vs. the actual grouping (Population) according to Statistics Canada (2014).

nificant differences were noted, a pairwise comparison of values was carried out using the same test to detect the main differences.

It was also necessary to determine a minimum number of respondents in this kind of study. Using a precision of 5\% and a confidence level of $90 \%$, we used the formula proposed by Lohr (1999) to assess the minimum required sample size in a finite population and this number was estimated at 196 for the present study.

\section{Sample grouping and description}

To explore the differences between municipalities, they were grouped according to three criteria: population, regions, and percentage of the municipality's canopy. We considered that these criteria were the most susceptible to influence the research needs, and thus in the end would provide a better insight into the priorities according to these municipality features.

Population was grouped according to the following categories: 5000-9999 inhabitants, 10000-19 999 inhabitants, 20000-49999 inhabitants, 50000-99 999 inhabitants, and 1000003000000 inhabitants. Data from Statistics Canada (2014) were used to divide municipalities into these different classes. For the purposes of analysis, we grouped the provinces into five regions: West, Centre, Ontario, Quebec and the Maritimes. For the percentage of canopy (forest cover), the following categories were considered: $0 \%$ to $10 \%, 11 \%$ to $20 \%, 21 \%$ to $30 \%, 31 \%$ to $40 \%, 41 \%$ to $50 \%$, and over $51 \%$.

\section{Results and discussion}

Representativeness and validity of the sampling

When compared with the theoretical population grouping adapted from Statistics Canada (Fig. 1), the sampling of our survey appears representative of the target Canadian cities, except in smaller municipalities where they are underrepresented. In all, 284 responses were received. Once duplicates and unanswered questions had been eliminated, 200 valid responses had been obtained. Eight of the respondents were not part of the target population, therefore we received 192 responses from the municipalities having at least 5000 residents, a sample size still considered fairly representative of the target municipalities. Seven of these participants did not respond to all the questions about the research needs, so some analyses were conducted with 185 respondents. In addition, some municipalities had more than one respondent, which explains why 166 different municipalities were selected in Fig. 2 where the size of municipalities was also analyzed according to the region. The largest municipalities were mostly located in Quebec and Ontario, although other population classes are also represented in these regions, especially municipalities with 10000 to 19999 inhabitants. It should be noted that all the other data were analyzed by taking into account all respondents (192 or 185, depending on the question). Even though we were not able to exactly reach the targeted 196 respondents as established according to Lohr (1999) in the Methodology, we still consider that the number of respondents is fairly adequate and even impressive for this kind of investigation.

Fig. 2. Size of municipalities according to regions $(n=166)$. 
Research needs

The needs of the municipalities surveyed are ranked in order of importance in Fig. 3. Of these 32 needs, the first seven have standard deviations that overlap so the difference between them is most likely not significant (von Bargen 2020). The research need at the top of the figure relates to tree species adaptability to the urban environment. As mentioned in the Introduction, it is not surprising that this would be identified as a need, since trees are under considerable stressors in urban areas, compared with rural environments. All these factors reduce the life expectancy of trees in urban areas and may result in expenses such as pruning and/or removal of these trees when planted in the wrong place (Dwyer et al. 1992). A survey conducted in Switzerland and France in 2004 (Gillig et al. 2008) indicated that urban trees live on average between 40 to 60 years, whereas their life expectancy is two to three times longer in natural settings.

The second need (Fig. 3) relates to trees and how they reduce the impact of rainwater runoff which is likely to occur more often in the future and with greater intensity, for instance in the province of Quebec (Ouranos 2015). In a Canadian synthesis on the subject regarding water management (Simard et al. 2019), this was addressed several times, and in particular, the ability of vegetation to help cities better cope with the increased frequency of floods. During intense floods, drainage scratches the surface of soils and can result in poorer soil conditions (Ordonez and Duinker 2014). Poor soil composition and low soil volume make root development difficult and directly affect the health of the trees in cities (Gillig et al. 2008).

Although the respondents were interested in soil conditions in urban environment, this topic only ranked $22^{\text {nd }}$ in the list of research needs (Fig. 3). In a study carried out by Tree Canada, the most urgent need for applied research which was identified by municipalities was the development of more favourable soil conditions in urban settings (Bardekjian et al. 2016). Since the design of the study and/or the wording of the questions are not exactly the same (e.g., "Developing better soil conditions" in Bardekjian et al. (2016) vs "Urban area soil mixtures" in the present study), this may explain why respondents rated them differently between the studies. In addition, the number of municipal respondents in both studies is significantly different, 26 compared to 192 .

The third research need which was identified relates to human health. With the current COVID-19 pandemic, had the survey been conducted presently, we postulate that this item would have received even more attention given that our mental health is particularly affected these days, as largely reported in the literature (see e.g., Tandon 2020).

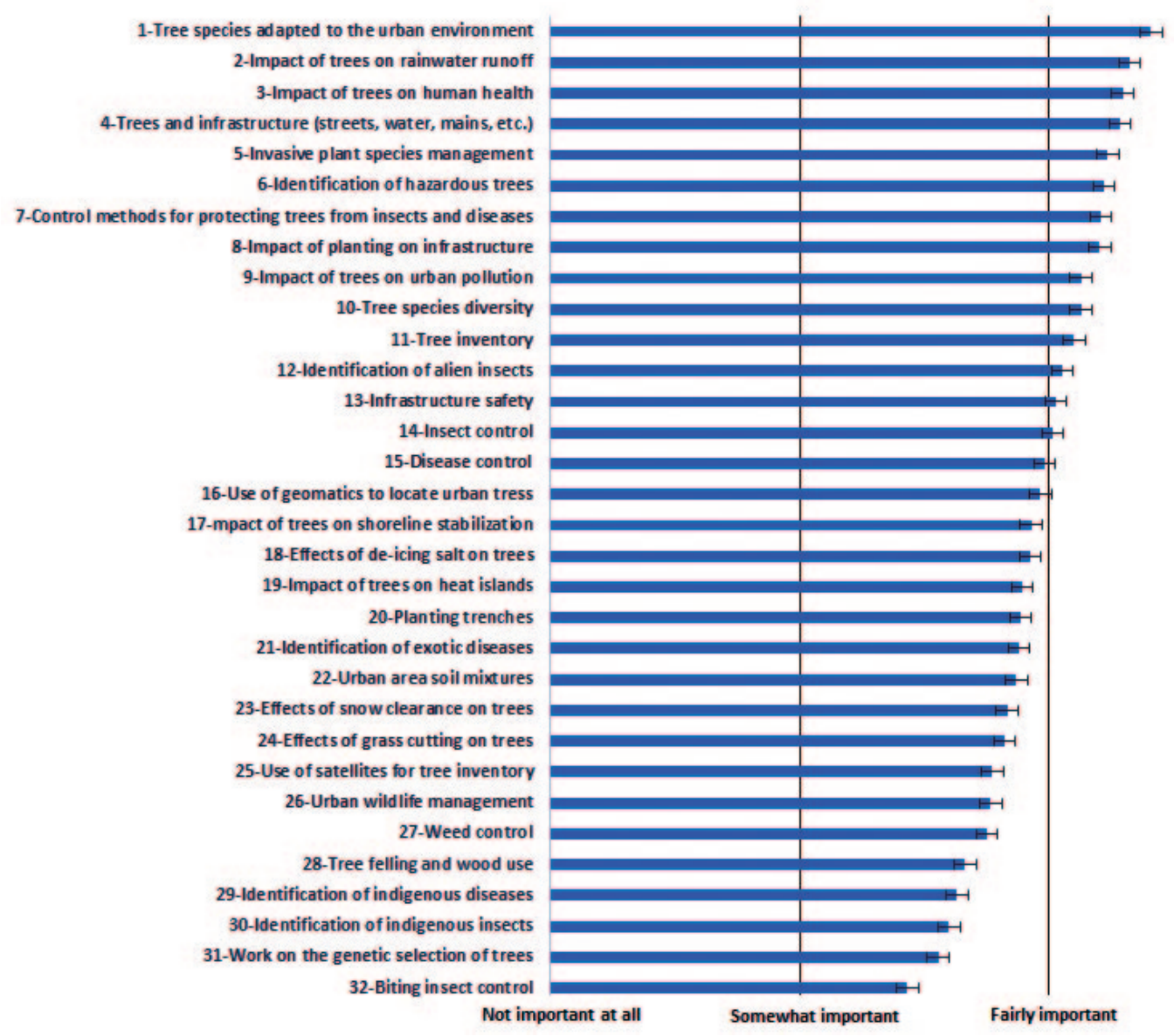

Fig. 3. Research needs of Canadian municipalities of 5000 inhabitants or more $(n=185)$. Bars $=$ Standard deviation. 
Even though studies have been conducted on strategies to avoid conflict between infrastructure and urban trees (e.g., McPherson 2000), this subject continues to preoccupy green space managers that would benefit from additional studies conducted on this topic ( $4^{\text {th }}$ position in Fig. 3). Actually, the infrastructure development, in the sense of hardscape in McPherson (2000), is now confronted with the "urban green infrastructure" (see e.g., the special issue of Urban Forestry \& Urban Greening, vol. 37, January 2019). The development of green infrastructure should be better promoted in the future to help urbanites better cope with the presence of other infrastructures, and obviously to better deal with the consequences of climate change, linked to the heat islands (19th position and ranked as fairly important in Fig. 3) and to an increase of pollution ( $9^{\text {th }}$ position in Fig. 3).

Many of the research needs identified in the current study (Fig. 3) had also been reported in other studies or during major scientific meetings (Rousseau 2004; Konijnendijk et al. 2007; Wolf and Kruger 2010; Tree Canada 2014; Bardekjian et al. 2016), for instance needs related to tree species that are well adapted to the urban environment, to better manage invasive plant species, and to properly identify hazardous trees. Urban green spaces planners are also preoccupied by the presence of pests, including the exotic ones (see e.g.,

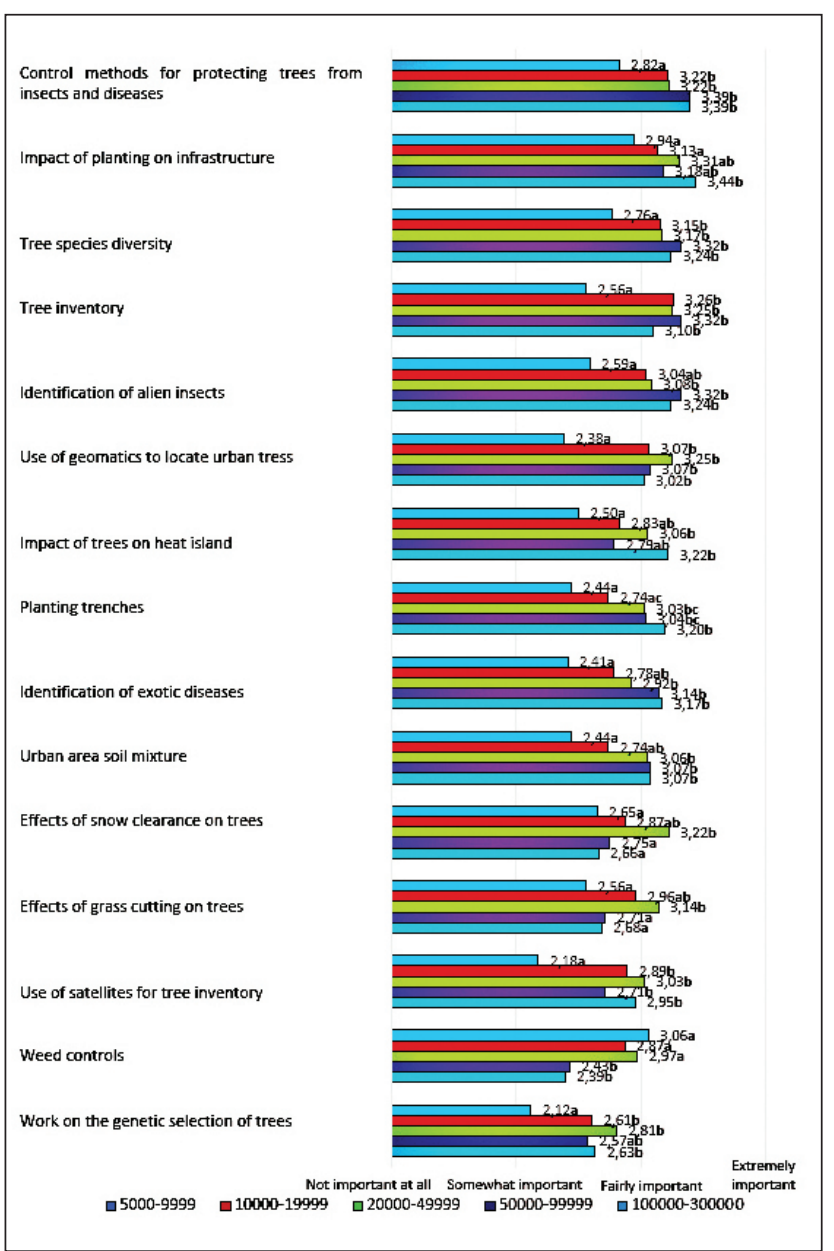

Fig. 4. Influence of the population when significant differences were noted during the analysis of research needs (values with a similar letter are not significantly different $(p \leq 0.05)(n=185)$.
"Control methods for protecting tree from insects and diseases" in $7^{\text {th }}$ position and "21. Identification of exotic diseases" evaluated as fairly important in Fig. 3). In support of this finding, "Insect control" and "Disease control" (14 $4^{\text {th }}$ and $15^{\text {th }}$ position, respectively) were also judged as important research needs by the respondents.

After identifying the research needs, we analyzed whether the size of the city (population), the region and the size of the urban forest (canopy) influenced the selection of research needs. The Kruskal-Wallis test revealed that 15 of the 32 needs presented in Table 1 showed significant differences $(p \leq 0.05)$ according to population, 5 of 32 according to the region, and none according to canopy cover size. When such significant differences were identified, a pairwise comparison of values was performed using the same test to determine where the differences were present (Figs. 4 and 5).

Respondents from smaller municipalities (5000 to 9999 residents) often have different perceptions of these needs (Fig. 4). Except for certain items such as "Impacts of planting on infrastructure", where a significant difference was noted only with the most populated cities, there was generally less interest in these needs, and this was considerable compared with all other cities of different sizes for the following needs: "Control methods for protecting trees from insects and diseases", "Tree species diversity", "Tree inventory", "Use of geomatics to locate urban trees" and "Use of satellites for tree inventory" (Fig. 4). The last three needs are all related to inventories, the backbone of many management plans (see e.g., Kenney and Idziak 2000; Konijnendijk 2003; Wolf and Kruger 2010). Bardekjian et al. (2016) reported that even though some Canadian cities have shifted from expectations to have an inventory, to an actual one over a period of 12 years, their survey also showed a slight increase in the proportion of municipalities over the same period that report having no inventory at all. When one combines the three previous needs related to inventories in Figure 3, it is clear that there is an unquestionable need in the municipalities surveyed to better measure their tree resource.

The fact that small municipalities are often located in rural areas, which usually contain a significant number of trees, may explain why they are less interested in many research needs. It is also possible that conducting such studies in these locations could represent a greater challenge in terms of resources per capita, especially difficulties to allocate a sufficient portion of their budget to urban forest management.

Although regions had less significant influence on the identification of needs, respondents from the Maritimes still seemed to be particularly interested in the five needs that showed significant differences, especially the "Effects of snow clearance on trees" and "Urban wildlife management," where the Maritimes stood out completely from the other regions (Fig. 5). The Maritimes receive heavy snowfall and are bordered by large bodies of water. For example, from 1981 to 2010, the average annual snowfall at airport weather stations was $325.3 \mathrm{~mm}$ for Moncton, $209.5 \mathrm{~mm}$ for Montréal (Pierre Elliot Trudeau station), $100.2 \mathrm{~mm}$ for Regina and $38.2 \mathrm{~mm}$ for Vancouver (Environment and Natural Resources Canada 2020). These elements might also justify the region's strong interest in the "Impact of trees on shoreline stabilization" and the "Effect of de-icing salt on trees".

Even if some of the research needs selected by the cities showed a significant effect when the "size of municipalities" 


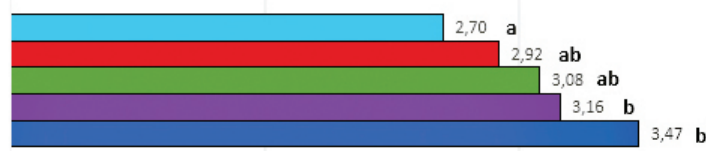

Impacts of trees on shoreline stabilisation

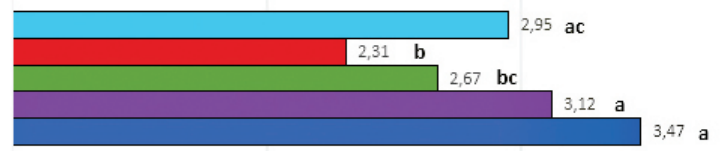

Effects of de-icing salt on trees
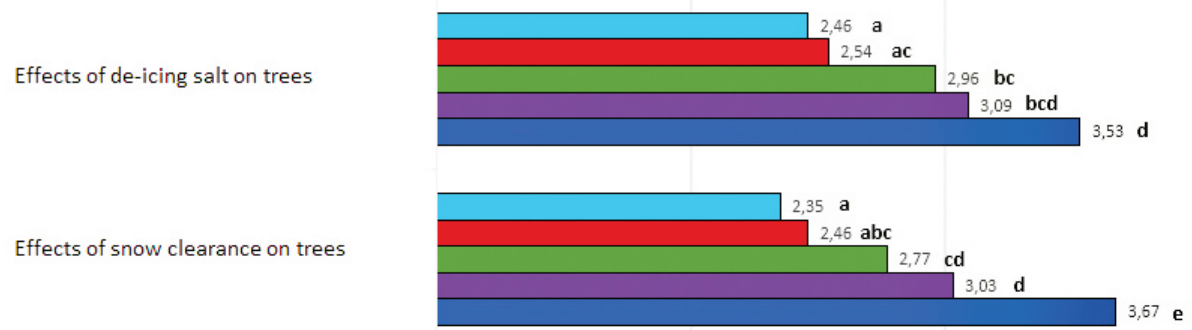

Urban wildlife management

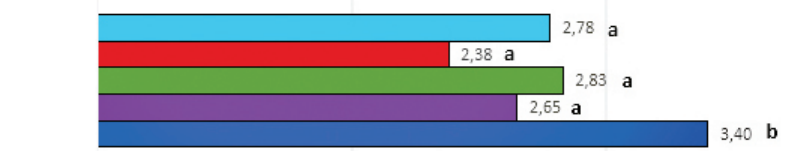

Not important at all Somewhat important $\quad$ Fairly important $\quad$ Extremely important

口West aCentral $\square$ Ontario $\square$ Quebec $\square$ Maritimes

Fig. 5. Influence of the regions when significant differences were noted during the analysis of research needs (values with a similar letter are not significantly different $(p \leq 0.05)(n=185)$.

and "regions" were analyzed, their canopy did not seem to influence the type of research sought by the municipalities. This may be surprising given our assumption that smaller cities, which expressed less interest in certain types of research as shown in Fig. 4, would also show a forest cover different from that of larger cities such as Toronto which generally aim to increase their canopy over the long term (City of Toronto 2013).

With regard to ongoing research (Table 2 ) reported by the municipalities, the responses showed a clear trend of more sustained activity in large municipalities (50000 to 3000000 inhabitants) where such cities represented 55\% (48) of the 87 municipalities that responded to our survey (unpublished results). Most of the activities reported by the cities were related to the emerald ash borer and pests in general, tree inventories, the right selection of tree species and their planting, and invasive plant species. Although these research topics are ongoing, they are still well represented in Fig. 3 among the current research needs reported by the respondents. If our survey were conducted in 2020 instead of 2015, one can imagine that even more cities would have reported studies on mitigating measures against the emerald ash borer as this insect continues to kill trees at great pace as it expands its geographic range in Canada (see e.g., CFIA 2020 and the various links therein).

Respondents were also asked to identify research needs other than those included in the suggested response options. The small number $(12 / 185)$ of new research needs proposed by the respondents seems to indicate that our list was quite extensive (unpublished results). These other needs included the effects of climate change on urban forests, the value of ecological services provided by trees in urban areas, and urban forest governance in municipalities.

Among the most important needs and those added by the respondents, it should be noted that some topics were already

Table 2. Types of ongoing research projects in municipalities

\begin{tabular}{lc}
\hline Research projects & Number of projects \\
\hline Emerald ash borer & 23 \\
Planting & 10 \\
Inventory & 9 \\
Tree species trials & 8 \\
Other pests & 8 \\
Invasive plants & 6 \\
Soil & 6 \\
Biodiversity & 4 \\
Survival of trees & 3 \\
Pollutants & 2 \\
Sustainable urban forest & 2 \\
Tree value & 2 \\
Management & 1 \\
Arboriculture & 1 \\
Wetlands & 1 \\
Policy & 1 \\
\hline Total & $\mathbf{8 7}$ \\
\hline
\end{tabular}


largely covered in the scientific literature, including tree diversity in urban areas (Nagendra and Gopal 2011; Kendal et al. 2014; Conway and Vander Vecht 2015), trees and infrastructure (Mullaney et al. 2015), and the impact of trees on pollution (Rao et al. 2014). Thus, it can be deduced from this survey and from a previous study (Larouche et al. 2019) that many municipalities do not seem to be aware of much of the research conducted in urban forestry. It would therefore be beneficial to improve the transfer of knowledge between researchers in these areas of study and users, as was previously noted by Konijnendijk et al. (2007). Another possible explanation for this discrepancy is that existing research in this area is inadequate or does not fully meet the needs of Canadian municipalities (Kenney 2003). Moreover, the subtleties in some studies are not always easy to grasp and entire sections can be difficult to interpret by the layperson, especially those including significant statistical analysis or complex tables or figures. Furthermore, it may be beneficial to examine in a further study the reasons for this lack of knowledge transfer in urban forestry. Is this due to staff turnover in urban forestry in municipalities? Does information flow better in large cities where there are teams devoted to urban forestry? Or do green space managers lack the interest or time to fully devote themselves to caring for the trees? In their survey, Johnston and Rushton (1999) indicated that green space managers spend an average of $20 \%$ of their time on activities other than tree maintenance, which is not insignificant, and this number varies according to the size of the municipality. As previously alluded to in our study, the smaller the municipality, the more likely the managers are to engage in activities not really directly related to urban forestry and this obviously might limit their time devoted to acquire knowledge from colleagues or education/outreach organizations, and even less from the scientific literature. In larger municipalities, more organized efforts include teams of specialists (forest engineers, technicians, arborists and horticulturists) in urban forestry (Larouche 2016).

Somewhat to our surprise, "climate change" was not mentioned in any way among the ongoing research activities in the municipalities (Table 2), even though the control of pollutants seemed to be of concern for two municipalities. It is quite possible that this type of study is too complex to be entirely coordinated by the cities, especially by stakeholders whose training focused solely or in part on forestry or plant biology. For example, in the study by Crouse et al. (2017) published in The Lancet Planetary Health which focuses on sustainable development and the environment, the authors, who are specialists in human health, used numerous resources such as large databases which, for instance, allowed them to highlight a link between good air quality/green spaces and an increased life expectancy for the residents of large Canadian cities.

In the present study, it should be noted that two needs closely related to climate change, the "9. Impact of trees on urban pollution" and the "19. Impact of trees on heat islands" were proposed to the respondents and clearly drew their attention among their research needs (Fig. 3). That being said, even though this subject has been reported, it is quite possible, especially in large cities more likely to have urban forestry specialists who are well versed in the literature, that the two needs mentioned above were obvious to these respondents and that their efforts are currently mainly focused for instance on locating these heat islands and planning how they can actually increase the canopy there.

\section{Limitations of the survey}

The number of incomplete questionnaires is partly due to the use of LimeSurvey 1.91. This software did not allow respondents to begin filling out the questionnaire and then complete it later, which would have been easier for them. We also did not have a list of the respondents' emails (responses were anonymous) to contact them and remind them to complete the questionnaire. We consider that this situation probably discouraged a number of participants from filling out the entire questionnaire.

Regarding the canopy, 63 respondents were unable to select a percentage of forest cover, which is why some analyses on this subject have an " $n$ " of 129. In addition, for this question, most respondents gave an approximate percentage of the canopy according to their best judgment, since they did not have accurate data on the subject. The question should have been asked more clearly using the term "canopy" or "forest cover" instead of "forest assets," which may have confused some respondents. Respondents should also have been asked to specify whether this proportion was roughly estimated or was already calculated in their database.

Many of the research needs mentioned in the questionnaire dealt with quite or similar topics (e.g., identification and control of various pests; see Nos. 7, 12, 14, 15, 21, 29, and 30 in Fig. 3). To facilitate data analysis, the list of these needs could have been reduced by simplifying their wording or merging some of the items. This element should be taken into consideration for a future survey of the same type.

Finally, even though the survey was conducted in 2015, we believe that most of the significant research needs would have been reported the same way had the questionnaire be sent in 2020. However, when one considers a specific insect pest such as the emerald ash borer, which has greatly expanded its geographic range in Canada in recent years (CFIA 2020), it is obvious that such a topic is currently more preoccupying in certain cities in 2020 than it was in 2015. The same could be said concerning the current impact of COVID-19 on our physical and mental health (Tandon 2020), where this disease might have had a greater influence on the responses received about the "Impact of trees on human health" ( $3^{\text {rd }}$ need in Fig. 3).

\section{Conclusion}

This study identified the urban forestry research needs of Canadian municipalities of 5000 inhabitants or more and ranked them according to their importance. Although we had difficulty reaching the smaller municipalities, where they do not necessarily have a specific person dealing with urban forestry, this survey is the first of the kind that has succeeded gathering so many respondents (192).

Several of the research needs identified by the respondents were concerned broadly, not surprisingly, with the health of trees (e.g., their adaption, the impact of various pests, weeds, and invasive plants, as well as that of de-icing salts) and of the well-being of the citizens (e.g., their health, pollution, trees vs infrastructures, and how to reduce the impact of heat islands). The responses received also stressed that there are 
needs related to inventories (e.g., Nos. 11, 16, and 25 in Fig. 3) to better assess the resource "urban trees" and this appears to be linked to the fact that we have found that most cities did not have any precise data concerning their actual canopy. Although it was underscored in the present work that some of these needs were also reported in other studies, our survey gives for the first time an extensive view of these needs in a Canadian perspective.

The study also looked at these needs when the influence of the region, the population, and the canopy were considered. Our analyses revealed that the size of the municipality and the region have a significant impact on research needs. For example, it was clear that small municipalities showed less interest in these needs while the Maritimes were more eager than other regions to see resources dedicated to studies such as the effect of snow clearance on trees. Unexpectedly, no effect of the canopy on research needs was noted, although we cannot easily explain why differences in forest cover in the respondents' municipalities did not influence their needs. The fact that most respondents seem to have estimated only an approximate percentage of the canopy may indicate the lack of interest of some municipalities in this criterion, which consequently affected the quality of the results obtained.

The survey also revealed a lack of knowledge transfer between researchers and users. Municipalities do not seem to be aware of several of the main studies in urban forestry already present in the literature, which is understandable to some extent since, for instance, there is an increasing number of journals and scientific publications of all kinds, and most require a fee to gain access. It then becomes imperative that outreach officers get involved to better explain to cities the key results of these studies in simple terms, especially the concrete actions they can take to improve the health of trees and their citizens. It would also be beneficial that an organization, such as a chair in urban forestry, coordinate these knowledge transfer activities through their involvement in City's communication instruments and tools such as social media (website, blog, Twitter, etc.).

Extreme events related to climate change, such as water management and the ability of vegetation to help cities cope with increasing flood (Simard et al. 2019) could become our best support in selling "the importance of trees in the city". Investing in trees, especially in our cities, is an important asset for various facets of human health, particularly these days when we have to deal with a serious coronavirus pandemic. In addition, it is now well established that trees help counteract the effects of pollution in cities (see e.g., Rao et al. 2014), a significant acknowledgment when one considers that outdoor pollution, mainly in cities, would have been responsible for the death of 4.2 million people worldwide in 2016 (World Health Organization 2018). Another paper, a review of reviews as called by the authors (van den Bosch and Ode Sang 2017), showed that there is evidence that reduced spaces of urban greenness would be associated with cardiovascular mortality. This again stresses that since trees play multiple positive roles in urban settings, not the least of which being the improvement of air quality, we have everything to gain from enhancing the green infrastructure in our cities as well as supporting further studies that will most likely reveal that the benefits of trees in municipalities go even beyond our most optimistic expectations.
Thus, our study, the most extensive survey of this kind, found that Canadian cities still have many research needs in urban forestry. It has also helped provide researchers with guidelines to better define their research priorities in this field. Moreover, this study clearly indicates that a way must be found to improve the transfer of scientific knowledge to municipalities if we want to implement effective tools and strategies to increase, enhance, and sustain our urban green canopy nationwide.

\section{Acknowledgments}

We would like to thank Ève Richard, forestry engineer, M.S.I., and librarian at Université Laval for her support and helpful advice. We would also like to thank Guy Bussières, forestry engineer, in charge of practical work and research, Faculty of Forestry, Geography and Geomatics at Université Laval and Louis Bernier, professor, Faculty of Forestry, Geography and Geomatics at Université Laval, for their valuable advice.

\section{References}

Alexander, C. and B. DePratto. 2014. The value of urban forests in cities across Canada. Special report. TD Economics. 5 p.

Alexander, C. and C. McDonald. 2014. Urban forests: The value of trees in the city of Toronto, Special Report, TD Economics. 4 p.

Bardekjian, A.C., A. Kenney and M. Rosen 2016. Trends in Canada's urban forests. Tree Canada, Ottawa. 34 p.

Berman, M.G., E. Kross, K.M. Krpan, M.K. Askren, A. Burson, P.J. Deldin, S. Kaplan, L. Sherdell, I.H. Gotlib and J. Jonides. 2012. Interacting with nature improves cognition and affect for individuals with depression. J. Affect. Disorders 140: 300-305.

Bissonnette, J.-F., J. Dupras, C. Messier, M. Lechowicz, D. Dagenais, A. Paquette, J.A.G. Jaeger and A. Gonzalez. 2018. Moving forward in implementing green infrastructures: Stakeholder perceptions of opportunities and obstacles in a major North American metropolitan area. Cities 81: 61-70. https://doi.org/10.1016/j.cities. 2018.03.014.

CFIA 2020. (Canadian Food Inspection Agency). Emerald ash borer - Latest information. Available at https://www.inspection. gc.ca/plant-health/plant-pests-invasive-species/insects/emeraldash-borer/latest-information/eng/1337287614593/1337287715022 [Accessed December 21, 2020].

City of Toronto. 2013. Sustaining and expanding the urban forest: Toronto's strategic forest management plan, 2012-2022. Toronto, Ontario. City of Toronto, Parks, Forestry and Recreation, Urban Forestry. $61 \mathrm{p}$.

Conway, T.M. and J. Vander Vecht. 2015. Growing a diverse urban forest: Species selection decisions by practitioners planting and supplying trees. Landscape Urban Plan 138: 1-10.

Crouse, D.L., L. Pinault, A. Balram, P. Hystad, P.A. Peters, H. Chen, A. van Donkelaar, R.V. Martin, R. Ménard, A. Robichaud and P.J. Villeneuve. 2017. Urban greenness and mortality in Canada's largest cities: A national cohort study. Lancet Planet Health 1: e289-97.

Donovan, G.H, D.T.B. Butry, Y.L. Michael, J.P. Prestemon, A.M. Liebhold, D. Gatziolis and M.Y. Mao. 2013. The relationship between trees and human health: Evidence from the spread of the emerald ash borer Am. J. Prev. Med. 44: 139-145.

Dwyer, J.F., E.G. McPherson, H.W. Schroeder and R.A. Rowntree. 1992. Assessing the benefits and costs of the urban forest. J. Arboric. 18: 227-234.

Environment and Natural Resources 2020. Canadian climate normals. 1981-2010 Climate normals and averanges. Available at https://climate.weather.gc.ca/climate_normals/index_e.html [Accessed April 13, 2020]. 
FAO 2000. (Food and Agriculture Organization of the United Nations). Urban forestry issues in North America and their global linkages. Abstract 20th session of North American Forest Commission, St-Andrews, New Brunswick, Canada, FAO, p. 13 [Online]. Available at http://www.fao.org/3/X4999e/X4999e.htm [Accessed July 31, 2019].

Gillig, C.-M, C. Bourgery et N. Amann. 2008. L'arbre en milieu urbain : conception et réalisation de plantations. Infolio Éditions, Lullier. $216 \mathrm{p}$.

Howley, D. 2007. Les arbres, une valeur ajoutée. Paru dans La Presse. Édition du $1^{\text {er }}$ juin. Available at https://www.lapresse.ca/ maison/cour-et-jardin/jardiner/200706/01/01-870423-les-arbresune-valeur-ajoutee.php [Accessed March 25, 2021].

Johnston, M. and B.S. Rushton 1999. A survey of urban forestry in Britain. University of Ulster, Northern Ireland. 66 p.

Kendal, D., C. Dobbs and V.I. Lohr. 2014. Global patterns of diversity in the urban forest: Is there evidence to support the 10/20/30 rule? Urban Forestry and Urban Greening. 13: 411-417.

Kenney, W.A. 2003. A strategy for Canada's urban forests. For. Chron. 79: 785-789.

Kenney, W.A. and C. Idziak. 2000. The state of Canada's municipal forests - 1996 to 1998. For. Chron. 76: 231-234.

Konijnendijk, C.C. 2003. A decade of urban forestry in Europe. Forest Policy Econ. 5: 173-186.

Konijnendijk, C.C., T.B. Randrup and K. Nilsson. 2000. Urban forestry research in Europe: An overview. J. Arboric. 26: 152-161.

Konijnendijk, C.C., A.B. Nielsen, J. Schipperijn, Y. Rosenblad, H. Sander, M. Sarv, K. Mäkinen, L. Tyrväinen, J. Donis, V. Gundersen, U. Akerlund and R. Gustavsson. 2007. Assessment of urban forestry research and research needs in Nordic and Baltic countries. Urban Forestry and Urban Greening 6: 297-309.

Labrecque, M. and T.I. Teodorescu. 2005. Preliminary evaluation of living willow (Salix spp.) sound barrier along a highway in Québec, Canada. J. Arboric. 31: 95-98.

Larouche, J. 2016. Foresterie urbaine: recensement mondial des publications, situation actuelle et besoins de recherche des municipalités canadiennes. Mémoire de maîtrise en sciences forestières. Université Laval. 120 p.

Larouche, J., D. Rioux, A.C. Bardekjian A. C. and N. Gélinas. 2019. Inventory of scientific publications on urban forestry published between 1800 and 2015: An analysis by period, topic and origin. For. Chron. 95: 91-100.

Lohr, S.L. 1999. Sampling: Design and analysis. Brooks/Cole publishing company. Pacific Grove. California. 493 p.

McPherson, E.G. 2000. Expenditures associated with conflicts between street tree root growth and hardscape in California, United States. J. Arboric. 26: 289-297.

Mullaney, J., T. Lucke and S.J. Trueman. 2015. A review of benefits and challenges in growing street trees in paved urban environments. Landscape and Urban Planning 134: 157-166.

Nagendra, H. and D. Gopal. 2011. Tree diversity, distribution, history and change in urban parks: Studies in Bangalore, India. Urban Ecosystems 14: 211-223.

Ordonez, C. and P.N. Duinker 2014. Assessing the vulnerability of urban forests to climate change. Environ. Rev. 22: 311-321. doi.org/10.1139/er-2013-0078.

Ouranos. 2015. Vers l'adaptation. Synthèse des connaissances sur les changements climatiques au Québec. Available at http://www. ouranos.ca/fr/synthese2015/doc/Complet.pdf [Accessed Marsh 26, 2021]. Edition 2015, Montréal. 415 p.
Ramousse, R., M. Leberre and L. Le Guelte. 1996. Introduction aux statistiques. Available at http://www.cons-dev.org/elearning/ stat/St2b.html [Accessed November 7, 2019].

Rao, M., L.A. George, T.N. Rosenstiel, V. Shandas and A. Dinno. 2014. Assessing the relationship among urban trees, nitrogen dioxide, and respiratory health. Environ. Pollut. 194: 96-104.

Rousseau, M.-H. 2004. État de la foresterie urbaine au Québec. Projet de fin d'études. Université Laval. 61 p.

Sangster, M., A.B. Nielsen and A. Stewart. 2011. Briefing Paper 1: The physical (peri)-urban forestry resource in Europe. Workshop on sharing experiences on urban and periurban forestry. Brussels. $20 \mathrm{p}$.

Simard, C., C. L'Ecuyer-Sauvageau, J.-F. Bissonnette and J. Dupras. 2019. Le rôle des infrastructures naturelles pour la gestion des eaux de ruissellement et des crues dans un contexte d'adaptation aux changements climatiques. Le Naturaliste canadien 143 no. 1 (winter edition).

SPSS de l'Université de Sherbrooke. 2013. Alpha de Cronbach. Available at http://spss.espaceweb.usherbrooke.ca/pages/interdependance/alpha-de-cronbach.php. [Accessed July 31, 2019] and http://spss.espaceweb.usherbrooke.ca/pages/interdependance/alph a-de-cronbach/interpretation.php.[Accessed July 31, 2019].

Statistics Canada. 2014. Chiffres de population et des logements, Canada, provinces et territoires, et subdivisions de recensement (municipalités), recensements de 2011 et 2006. Available at https://www12.statcan.gc.ca/census-recensement/2011/dp-pd/ hlt-fst/pd-pl/Table-Tableau.cfm LANG $=$ Fra $\&$ T $=308 \& S R=$ $1 \& \mathrm{~S}=8 \& \mathrm{O}=\mathrm{A} \& \mathrm{RPP}=25 \& \mathrm{PR}=24$ [Accessed July 31, 2019].

Tandon, R. 2020. COVID-19 and mental health: Preserving humanity, maintaining sanity, and promoting health. Asian J. Psychiatry 51 Article \# 102256

Tree Canada. 2012. Canadian Urban Forest Strategy 2013-2018. https://reecanada.ca/wp-content/uploads/2017/10/CUFN-RCFU2013-2018-EN-Canadian-Urban-Forest-Strategy.pdf [Accessed November 21, 2020].

Tree Canada. 2014. Canadian Urban Forest Conference. Available at https://treecanada.ca/wp-content/uploads/2017/11/2014-CUFCproceedings.pdf [Accessed July 31, 2019].

van den Bosch, M. and A. Ode Sang. 2017. Urban natural environments as nature-based solutions for improved public health-a systematic review of reviews. Environmental Research 158: 373-84. von Bargen, G. 2020. Interpreting error bars. In Biology for life. Available at https://www.biologyforlife.com/interpreting-errorbars.html [Accessed September 27, 2020].

Wolf, K.L. 1998. Tree in business districts: Positive effects on consumer behavior! Fact sheet \#5. Seattle: University of Washington, College of Forest Resources, Center for Urban Horticulture. 2 p.

Wolf, K.L. and L.E. Kruger. 2010. Urban forestry research needs: A participatory assessment process. J. Forestry, January/February. pp. 39-44.

World Health Organization. 2018. Ambient (outdoor) air pollution. Available at https://www.who.int/news-room/fact-sheets/ detail/ambient-(outdoor)-air-quality-and-health [Accessed June 16, 2020]. 